\title{
A construção da notícia internacional na imprensa brasileira
}

\author{
JOSÉ FLÁVIO SOMBRA SARAIVA
}

Na ocasião em que lançou o segundo número do quadragésimo-segundo ano de publicação da Revista Brasileira de Política Internacional (RBPI), o Instituto Brasileiro de Relações Internacionais (IBRI) promoveu seminário de impacto junto à opinião pública, no dia 23 de novembro de 1999. Reuniu, no Auditório da Reitoria da Universidade de Brasília, cerca de 100 pessoas interessadas em discutir o papel da imprensa brasileira na construção da notícia internacional nas páginas dedicadas ao mundo em nossos jornais. Os objetivos principais eram o de avaliar as condições da produção da notícia, seu conteúdo e qualidade, bem como sua relação com o pensamento brasileiro em matéria internacional.

Ao se dirigirem a um grande público estudantil presente ao evento, os professores, diplomatas e jornalistas presentes ao seminário procuraram discutir o contexto de ampliação do alcance dos temas internacionais na vida cotidiana dos brasileiros. Essa nova realidade, ao criar condições para crescente demanda por especialistas internacionais que possam atuar no ambiente das editorias e cadernos internacionais de jornais brasileiros, exige um novo tipo de profissional. Nesse sentido, a reflexão acadêmica brasileira no âmbito das relações internacionais mostra crescente desenvoltura e amplia sua responsabilidade na formação de quadros nacionais mais preparados na área.

Estiveram presentes o Ministro Luiz Fernando Ligiéro, chefe da assessoria de comunicação social do Ministério das Relações Exteriores, os jornalistas Luiz Recena, diretor da Gazeta Mercantil do Distrito Federal, Luis Orlando Carneiro, do Jornal do Brasil, Paulo Eduardo Nogueira, editor internacional de O Estado de São Paulo, e Helio Doyle, editor internacional do Correio Braziliense. O último jornal apoiou financeiramente o evento.

Alguns temas chamaram a atenção do público. Em primeiro lugar, a insistência, por parte dos editores internacionais brasileiros, na idéia de que se têm dado importância diminuta às notícias do mundo nos nossos jornais. Paulo Eduardo Nogueira afirmou que a imprensa brasileira caminha na contramão da globalização, preferindo contentar-se com o "próprio umbigo, retraída”. Para o editor internacional de O Estado de São Paulo, o autoritarismo político vivido pelo Brasil nas décadas de sessenta, setenta e parte da de oitenta, bem como as sucessivas crises econômicas que assolaram o país, limitaram a capacidade criativa da imprensa na 
área internacional. A cobertura dos temas internacionais, quase sempre realizada de maneira oficialesca, não teria conseguido cativar o público leitor dos jornais do país.

Em segundo lugar, observou-se a dificuldade de recrutamento de profissionais voltados para a área internacional. O jornalista Hélio Doyle, em especial, sublinhou a dificuldade em convencer colegas sobre a relevância da inclusão dos fatos internacionais. O editor do Correio Braziliense mencionou a revolução processada naquele jornal, ao trazer para o primeiro caderno as matérias internacionais, bem como sua ênfase em temas aparentemente tangenciais às grandes agências internacionais de notícias. Referiu-se explicitamente à maneira, quase precoce, com que o Correio Braziliense abordou os conflitos independentistas no Timor Leste. Comentou o jornalista as reações de colegas que desconheciam a existência do Timor. Segundo Doyle, foi necessário que o massacre chegasse, naquela região, a níveis críticos, para que a notícia enquanto tal fosse valorizada.

Um terceiro tema que chamou a atenção dos participantes foi a discussão, promovida por vários dos jornalistas presentes, acerca da retração financeira dos jornais brasileiros. O impacto imediato foi a redução, ou quase exclusão total, da figura clássica do correspondente brasileiro no exterior. Contenção de grande impacto para a formação de um ângulo nacional na abordagem da notícia internacional, a diminuição da presença desses correspondentes no corpo profissional dos jornais foi matéria de grande preocupação para os presentes. Nesse sentido, o editor da Gazeta Mercantil Luís Recena chamou a atenção para o fato de já ter existido no Brasil um bom jornalismo internacional. Como correspondente em Moscou por mais de quatro anos e em Paris por dois anos e meio, Recena reclamou da censura política interna dos jornais na época da ditadura militar brasileira e de um certo comodismo dos empresários de comunicação no Brasil.

A questão do ângulo nacional na construção da notícia internacional acalorou o debate. A crítica realizada, por vários dos presentes, à compra indiscriminada de pacotes com matérias e artigos de agências de notícias internacionais foi explícita. A utilização desse expediente, que sai mais barato financeiramente para os empresários de comunicação brasileiros, terminou por reduzir a importância estratégica do correspondente internacional, normalmente antenado com as demandas de uma informação genuinamente voltada para uma opinião pública brasileira, com uma formação exígua sobre os temas internacionais. Ao mesmo tempo, as agências internacionais trabalham tecnicamente muito bem, mas não são capazes de contextualizar e explicar os fatos de forma harmônica para todos os países onde mandam suas notícias, comentou Luís Recena. Em outras palavras, estaria faltando um certo olhar brasileiro na interpretação dos fatos emanados pelos grandes conglomerados de comunicação mundial.

Um quarto tema apresentado pelos debatedores foi sugerido pelo diplomata Luiz Fernando Ligiéro ao chamar a atenção para a desproporcionalidade de notícias 
internacionais em grande jornais estrangeiros, como o Financial Times, o Times e o Le Monde, quando comparados com os jornais brasileiros. Sugeriu a proporção de dez notícias nos grandes jornais estrangeiros para uma apenas nos nossos jornais de maior circulação e projeção.

Finalmente, discutiu-se o papel dos centros de pensamento internacionalista no Brasil e crescente valorização, na chancelaria brasileira, de uma notícia melhor construída nos nossos jornais. Foi registrado o esforço do Ministério das Relações Exteriores em intensificar o diálogo com a imprensa para que ela passe a desenvolver uma melhor reflexão sobre a política exterior do Brasil. Ao mesmo tempo, os acadêmicos presentes, especialmente os dos programas de pesquisa e docência em relações internacionais da Universidade de Brasília, manifestaram-se favoráveis a uma agenda de cooperação com as editorias internacionais dos jornais brasileiros. Nesse sentido, fez-se ecoar no Auditório a proposta do desenvolvimento de uma área, na formação do especialista em relações internacionais no Brasil, voltada para a reflexão crítica da produção da notícia internacional. Essa ponte, que se faz necessária e necessita ser urgentemente construída, foi o estímulo inicial que levou o Instituto Brasileiro de Relações Internacionais a promover o seminário de 23 de novembro de 1999.

Maio de 2000 